\title{
AKTIVITAS ANTELMINTIK EKSTRAK ETANOL 96\% DAUN SUKUN (Artocarpus altilis) TERHADAP Ascaridia galli SECARA In Vitro
}

\author{
Herson Cahaya Himawan ${ }^{1 *}$, Sofyan Ramani $^{1}$, Andi Hamonangan ${ }^{1}$ \\ Prodi S1 Farmasi Sekolah Tinggi Teknologi Industri dan Farmasi Bogor Indonesia \\ Korespondensi: hersonindonesia2011@ gmail.com
}

\begin{abstract}
ABSTRAK
Infeksi cacing usus yang utama disebabkan oleh cacing Ascaris lumbricoides, infeksi ini memiliki tingkat prevalensi cukup tinggi di Indonesia sehingga memerlukan pengobatan. Penelitian ini bertujuan untuk mengetahui aktivitas antelmintik ekstrak etanol 96\% daun sukun (Artocarpus altilis) terhadap cacing Ascaridia galli dengan berbagai konsentrasi ekstrak yaitu 5\%, 10\% dan 15\%. Penelitian uji aktivitas antelmintik ini dibagi menjadi 3 kelompok perlakuan, Konsentrasi 5\%, $10 \%$ dan $15 \%$ dari ekstrak etanol $96 \%$ merupakan kelompok perlakuan.Kelompok perlakuan kontrol positif dengan Pirantel pamoat $0,25 \%$ dan $\mathrm{NaCl} 0.9 \%$ merupakan kelompok kontrol negatif. Masing-masing kelompok perlakuan dilakukan dengan metode perendaman pada cacing Ascaridia galli. Hasil penelitian menunjukkan bahwa aktivitas antimiltik ekstrak etanol dengan konsentrasi $15 \%$ dari daun sukun (Artocarpus altilis) lebih baik dari ekstrak daun sukun yang memiliki konsentrasi 5\% dan $10 \%$. Hasil penelitian menunjukkan konsentrasi yang lebih besar dari ekstrak etanol daun sukun (Artocarpus altilis) akan menghasilkan aktivitas antelmintik yang lebih baik terhadap cacing Ascaridia galli, sktivitas yang lebih baik ini ditunjukkan dari data aktivitas pada konsentrasi i 5\%, $10 \%$ dan $15 \%$.
\end{abstract}

\section{Kata Kunci :Antelmintik; Artocapus Altilis ; Ascaridia galli ;Daun Sukun; Etanol $96 \%$.}

\begin{abstract}
The main intestinal helminth infection is caused by the Ascaris lumbricoides worm, this infection has a fairly high prevalence rate in Indonesia that requires treatment. This study aims to determine the anthelmintic activity of $96 \%$ ethanol extract of breadfruit leaves (Artocarpus altilis) against Ascaridia galli worms with various extract concentrations of 5\%,10\% and $15 \%$. This anthelmintic activity test study was divided into 3 treatment groups, the concentration of 5\%,10\% and $15 \%$ of 96\% ethanol extract constituted the treatment group. The positive control treatment group with Pirantel pamoate $0.25 \%$ and $0.9 \% \mathrm{NaCl}$ were the negative control group. Each treatment group was carried out by immersion method in Ascaridia galli worms. The results showed that the etymic activity of ethanol extract with a concentration of $15 \%$ of breadfruit leaf (Artocarpus altilis) was better than breadfruit leaf extract which had a concentration of $5 \%$ and $10 \%$. The results showed a greater concentration of ethanol extract of breadfruit leaves (Artocarpus altilis) would produce better anthelmintic activity against Ascaridia galli worms. This better activity was shown from the activity data at concentrations i $5 \%, 10 \%$ and $15 \%$.
\end{abstract}

\section{Keyword : Anthelmintic; Artocarpus altisis; Ascaridia galli; Sukun Leaves;Ethanol 96\%}

\section{PENDAHULUAN}

Salah satu problema bidang kesehatan dinegara berkembang termasuk Indoneisa adalah infeksi cacing usus. termasuk Indonesia. Pada manusia cacing Ascaris lumbri coides (cacing gelang) dapat menimbulkan infeksi yang disebut Ascariasis. Ascariasis merupakan infeksi yang disebabkan oleh cacing Ascaris lumbri coides(cacing gelang) yang sering terjadi pada manusia (Rasmiliah, 2001). Ascariasis juga terjadi pada unggas, disebabkan oleh cacing Ascaridia galli yang merupakan cacing nematoda dan famili yang sama dengan cacing Ascaris lumbricoides (Levine, 1990). Walaupun bernematoda dan famili yang sama dengan Ascaris limbricoides namun manusia jarang diserang oleh Ascaridia galli ,termasuk pada saat daging ayam dikonsumsi oleh 


\section{2 | Herson Cahaya Himawan et, al.,( Aktivitas Antelmintik Ekstrak Etanol 96\% ...)}

manusia dalam upaya memenuhi kebutuhan protein hewani yang menjadi inang cacing tersebut ada kemungkinan manusia terinfeksi. (Budhiet al., 2013).

Obat yang dipakai untuk mengurangi atau memusnahkan cacing dijaringan tubuh atau lumen usus. (Dirjen POM, 2007). Obat cacing sintesis yang tersedia dan dijual bebas di apotek harganya relatif mahal dan memiliki efek samping, salah satunya adalah pirantel pamoat. Pirantel pamoat akan mengakibatkan depolarisasi padacacing dan menimbulkan efek samping diare muntah dan mual.

Salah satu tanaman yang memiliki potensi sebagai obat cacing atau antimeltik adalah daun sukun (Artocarpus altilis). Hasil uji metabolit sekunder pada ekstrak etanol 96\% sukun (Artocarpus altilis) menunjukkan adanya senyawa fenol, flavonoid, alkaloid tanin dan saponin (Joni Tandi et al., 2017). Kandungan senyawa yang terdapat pada daun sukun, antara lain saponin alkaloid, fenol dan tanin diperkirakan berfungsi sebagai antelmintik atau obat cacing (Dara, 2017), tetapi hingga kini penelitian tentang itu belum pernah dilakukan. Penelitian ini bersifat eksperimental dengan menggunakan hewan uji cacing.Ascaridia galli.). Penggunaan cacingAscaridia galli sebagai hewan uji pada percobaan antelmintik ini didasari karena cacing ini memiliki kemiripan dengan nematode usus manusia, yaitu Ascaris lumbricoides baik dari segi anatomi, morfologi dan fisiologi. Penelitian ini memiliki tiga tujuan yaitu mengetahui kandungan senyawa yang terdapat pada ekstrak etanol 96\% daun sukun (Artocarpus altilis), mengetahui aktivitas antelmintik ekstrak etanol

\section{Determinasi Cacing}

Determinasi cacing Ascaridia galli dilakukan di Balai Besar Penelitian Veteriner Bogor (BB Livet).

\section{Pembuatan Simplisia}

Daun sukun (Artocarpus altilis) yang masih Simplisia yang sudah halus kemudian disimpan dalam segar, bewarna hijau dan tidak tua dikumpulkan sebanyak $5 \mathrm{~kg}$, kemudian dicuci sampai bersih menngunakan air yang mengalir agar menghilangkan kotoran yang melekat pada daun. Selanjutnya daun sukun dirajang dan dikeringkandengan cara didalam ruangan selama 5 sampai 6 hari.Daun sukun yang sudah kering kemudian ditimbang untuk mendapatkan berat keringnya. Diperoleh simplisia kering sebanyak $1,1 \mathrm{~kg}$, kemudian simplisia kering
96\% daun sukunterhadap cacing Ascaridia gallidan mengetahui perbedaan aktivitas antelmintik pada ekstrak etanol $96 \%$ daun sukun dan kontrol positif yaitu pirantel pamoat.

\section{METODE PENELITIAN \\ Alat dan Bahan}

Penelitian eksperimental ini menggunakan timbangan analitik (AD-300i), cawan penguap,rotary vacum evaporator (Janke \& kunkel RV 05-ST), dan waterbath (GCA Precision Scientific).

Pada penelitian ini digunakan bahan daun sukun, etanol 96\%, aquadest, cacing Ascaridia galli, $\mathrm{NaCl} 0,9 \%$, pereaksi fitokimia dan tablet pirantel pamoat.

\section{PROSEDUR PENELITIAN \\ Pengambilan Daun Sukun}

Daun sukun (Artocarpus altilis) yang dipakai untuk membuat ekstrak didapat dari Desa Karanggan Tua, Kecamatan Gunung Putri, Kabupaten Bogor. Kriteria pemilihan daun yang akan digunakan antara lain daun yang masih segar, berwarna hijau dan tidak terlalu tua. Diambil pada waktu pukul 09.00 WIB dengan jarak dari pucuk 4-5 tangkai, dipotong menggunakan pisau cutter.

\section{Determinasi Tanaman}

Determinasi bahan tumbuhan daun sukun (Artocarpus altilis) dilak dilakukan di LIPI (Lembaga Ilmu Pengetahan Indonesia) Laboratorium Biologi, Bogor.

wadah botol kaca gelap yang tertutup rapat.

Penetapan Kadar Air (AOAC, 2000) diblender hingga halus dan diayak dengan ayakan berukuran 40 mesh.

Sebanyak 5 gram simplisia daun sukun (Artocarpus altilis) dimasukan kedalam cawan porselin yang sudah diketahui bobot konstannya sebelum dipakai, kemudian diletakkan ke oven pada temperature dimasukan kedalam oven kembali suhu $105^{\circ} \mathrm{C}$ dalam waktu lebih kurang 3 jam.Cawan krus porselen yang berisi sampel kering dikeluarkan dari oven didinginkan menggunakan desikator dan ditimbang. Sampel kemudian dipanaskan kembali mengunakan oven \pm 20 menit pada temperature yang sama, didinginkan menggunakan desikator lantas ditimbang kembali. Perlakuan ini dilakukan sampai diperoleh bobot konstan. Penetapan kadar air menggunakan rumus perhitungan sebagai berikut : 
3 Herson Cahaya Himawan et, al.,( Aktivitas Antelmintik Ekstrak Etanol 96\% ...)

Penetapan Kadar Air (\%)

Keterangan :

$$
=\frac{A-(A 1-A 2)}{A} \times 100 \%
$$

A $\quad=$ Bobot sample sebelum dipanaskan (g)

A1 = Bobot cawan, tutupnya dan sample setelah dipanaskan $(\mathrm{g})$

W2 = Bobot cawan kosong, tutupnya yang sudah dipanaskan $(\mathrm{g})$

\section{Pembuatan Ekstrak}

Metode maserasi menggunakan etanol 96\% digunakan untuk mendapatkan ekstrak daun sukun. Simplisia dalam bentuk serbuk yang telah dihaluskan selanjutnya direndam kedalam pelarut etanol $96 \%$ lalu dimasukkan kedalam botol kaca gelap agar tidak terkena cahaya. Kemudian ditutup rapat dan dilapisi dengan alumunium foil selama $3 \times 24$ jam di dalam lemari, dimana setiap 1x24 jam pelarut diganti dan simplisia setiap 6 jam sekali diaduk. Maserat kemudian disaring menggunakan kertas saring dan ditampung dalam botol kaca gelap.Hasil maserasi dikumpulkan kemudian diuapkan di rotary evaporator.Selanjutnya sempurnakan denganwaterbathsampai mendapatkan ekstrak kental (Harbone, 1987).

\section{Uji Fitokimia}

Uji fitokimia ekstrak daun sukun (Artocarpus altilis) meliputi pemeriksaan

$\mathrm{NaCl} \quad 0,9 \% \quad$ (Rinaet al., 2017). Tahap pembuatan konsentrasi ekstrak etanol 96\% pada cacing Ascaridia galli. Sampel dikelompokkan menjadi lima kelompok percobaan, yaitu kelompok I pemberian larutan pirantel pamoat konsentrasi $0,25 \%$. sebagai kontrol positif , Kontrol negative yaitu $\mathrm{NaCl}$ Cawan petri a. Konsentrasi $5 \%$ b/v, 5 g ekstrak etanol $96 \%$ daun sukun dilarutkan dengan larutan $\mathrm{NaCl}$ $0,9 \%$ sampai $100 \mathrm{ml}$.

b. Konsentrasi $10 \% \mathrm{~b} / \mathrm{v}, 10 \mathrm{~g}$ ekstrak etanol $96 \%$ daun sukun dilarutkan dengan larutan $\mathrm{NaCl}$ 0,9\% sampai $100 \mathrm{ml}$.

c. Konsentrasi $15 \%$ b/v, 15 g ekstrak etanol daun sukun dilarutkan dengan larutan $\mathrm{NaCl}$ $0,9 \%$ sampai $100 \mathrm{ml}$.

\section{Pembuatan Larutan Pirantel Pamoat $0,25 \%$.}

Tablet Pirantel pamoat base $250 \mathrm{mg}$ dibuat halus dengan mortir, lalu serbuk diletakkan ke beaker glass selanjutnya di-larutkan golongan alkaloid, flavonoid, saponin, fenol dan tanin (Harbone, 1987).

\section{Hewan Uji}

Sampel yang digunakan adalah cacing Ascaridia galli, diperoleh dari lumen usus ayam bagian lumen. Cacing ini diambil dari ayam yang baru dipotong. Cacing tersebut berkarakteristik tidak tampak cacat, berukuran 7-11 cm dan masih aktif begerak.

Setelah itu sampel diletakkan ketoples dengan pinset anatomis yang berisi .larutan $\mathrm{NaCl}$ 0,9\% agar cacing tetap hidup dan aktif.Cacing Ascaridia galli yang dikumpulkan sebanyak 60 ekor.

\section{Pembuatan Konsentrasi Ekstrak}

Pembuatan variasi konsentrasi ekstrak kental daun sukun (Artocarpus altilis) yang dilakukan pada dalam penelitian ialah 5, 10 dan $15 \%$ b/vdimana konsentrasi ekstrak daun sukun diencerkan dengan larutan 0,9\% dikelompokkan kedalam kelompok II. Kelompok III sampai kelompok V, pemberian larutan ekstrak daun sukun dengan konsentrasi 5, 10 dan $15 \%$ b/v.Setiap kelompok diisi 6 cacing Ascaridia galli yang dimasukkan ke10 ml ekstrak etanol $96 \%$ daun sukun, larutan pirantel pamoat $0,25 \%$ serta $\mathrm{NaCl} 0,9 \%$ dengan masing-masing konsentrasi ekstrak etanol daun sukun.

Tahapan penelitian:

sejumlah tujuh buah disiapkan, setiap cawan diisi larutan $\mathrm{NaCl} \quad 0,9 \%$ sebagai kontrol negative, larutan ekstrak etanol dengan konsentrasi 5\%, 10\% dan 15\% dan Pirantel pamoat $0,25 \%$ sebagai kontrol positif. Masingmasing cawan petri diisi sebanyak 10 ml.daun sukun sebagai berikut.

menggunakan $\mathrm{NaCl}$ 0,9\% sampai $100 \mathrm{ml}$, sehingga larutan menjadi $0,25 \%$.

\section{Uji Aktivitas Antelmintik}

Sampel dibagi menjadi beberapa kelompok secara acak dengan metode random sampling

1. Dimasukkan kedalam cawan petri masing masing , sebanyak 6 ekor cacing Ascaridia galli yang masih bergerak aktif (normal)selanjutnya diinkubasi pada temperature $37^{\circ} \mathrm{C}$. Amati pergerakan dan perilaku cacing dan dicatat hasil nya setiap 15 menit. 
2. Tahap observasi dengan mengamati aktivitas cacing sesudah diinkubasi, dengan cara mengusik cacing menggunakan batang pengaduk. Bila cacing terlihat diam, kemudian diletakkan ke air panas dengan temperature $50{ }^{\circ} \mathrm{C}$, apa bila cacing masih tidak begerak , cacing tersebut dapat dinyatakan mati.

3. Hasil yang diperoleh kemudian dicatat untuk dilakukan analisis data. Cacing dikatakan mati bila jika pada penelitian tidak bergerak lagi ketika diletakkan ke air panas dengan temperature $50 \quad{ }^{\circ} \mathrm{C}$ selamadalam waktu kurang lebih 5 detik. Pengujian dilakukan 2 kali replikasi (duplo).

\section{HASIL DAN PEMBAHASAN}

Hasil Determinasi Tanaman

Determinasi menunjukkan

tanaman

yang dipakai pada penelitian ini tanaman sukun jenis Artocarpus altilis.

Hasil Uji Fitokimia Ekstrak Etanol 96\% Daun Sukun (Artocarpus altilis)

Dari identifikasi fitokimia yang sudah dilakukan, ekstrak kental daun sukun positif mengandung zat aktif seperti flavanoid alkaloid, fenol saponin dan tanin.

\section{Hasil Uji Aktivitas Antelmintik}

Pengamatan kematian cacing pada penelitian ini dapat dilihat dengan ditandainya

\section{Hasil Determinasi Cacing}

Hasil determinasi menunjukkan bahwa cacing merupakan cacing Ascaridia galli

\section{Hasil Penetapan Kadar Air Simplisia Daun Sukun}

Hasil kadar air yang didapat pada penelitian ini yaitu $6,73 \%$ yang artinya kadar air daun sukun telah memenuhi persyaratan.

\section{Hasil Pembuatan Ekstrak Kental Daun Sukun}

Serbuk Simplisia daun sukun dalam bentuk serbuk yang diesktraksi sebanyak $500 \mathrm{~g}$ dan mendapatkan hasil ekstrak kental daun sukun sebanyak 51,25 g. Sehingga rendemen yang diperoleh dari ekstrak adalah sebesar $10,25 \%$.

tubuh cacing yang sudah tidak bergerak atau tidak memberikan respon ketika diusik dengan pinset anatomis baik dalam larutan percobaan maupun ketika dimasukkan ke dalam air bersuhu $\quad 50^{\circ} \mathrm{C} \quad$ (Kendyartanto, 2008). Di masukkannya cacing ke dalam air panas bertujuan untuk memastikkan bahwa cacing benar-benar mati.

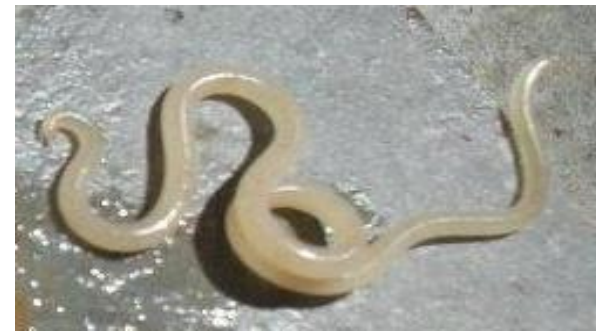

(A)

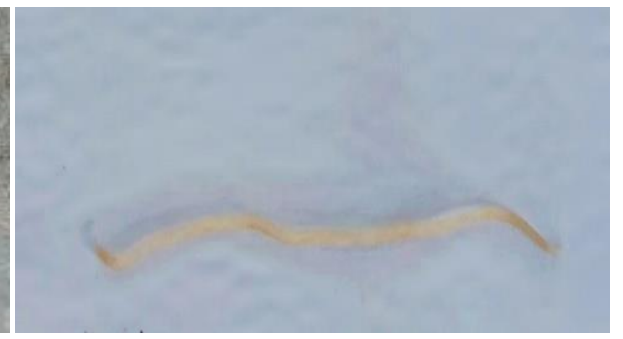

(B)

Gambar 1. Cacing Ascaridia galli Hidup dan Mati Keterangan gambar :

(A) Cacing Ascaridia galli Hidup

(B) Cacing Ascaridia galli Mati

Pada gambar 1, merupakan ciri-ciri morfologi cacing Ascaridia galli hidup ditandai dengan bagian tubuh cacing berlendir dan berwarna kekuningan.Sedangkan ciri-ciri morfologi cacing Ascaridia galli mati ditandai dengan badan cacing sudah kaku dan berwarna putih pucat. 


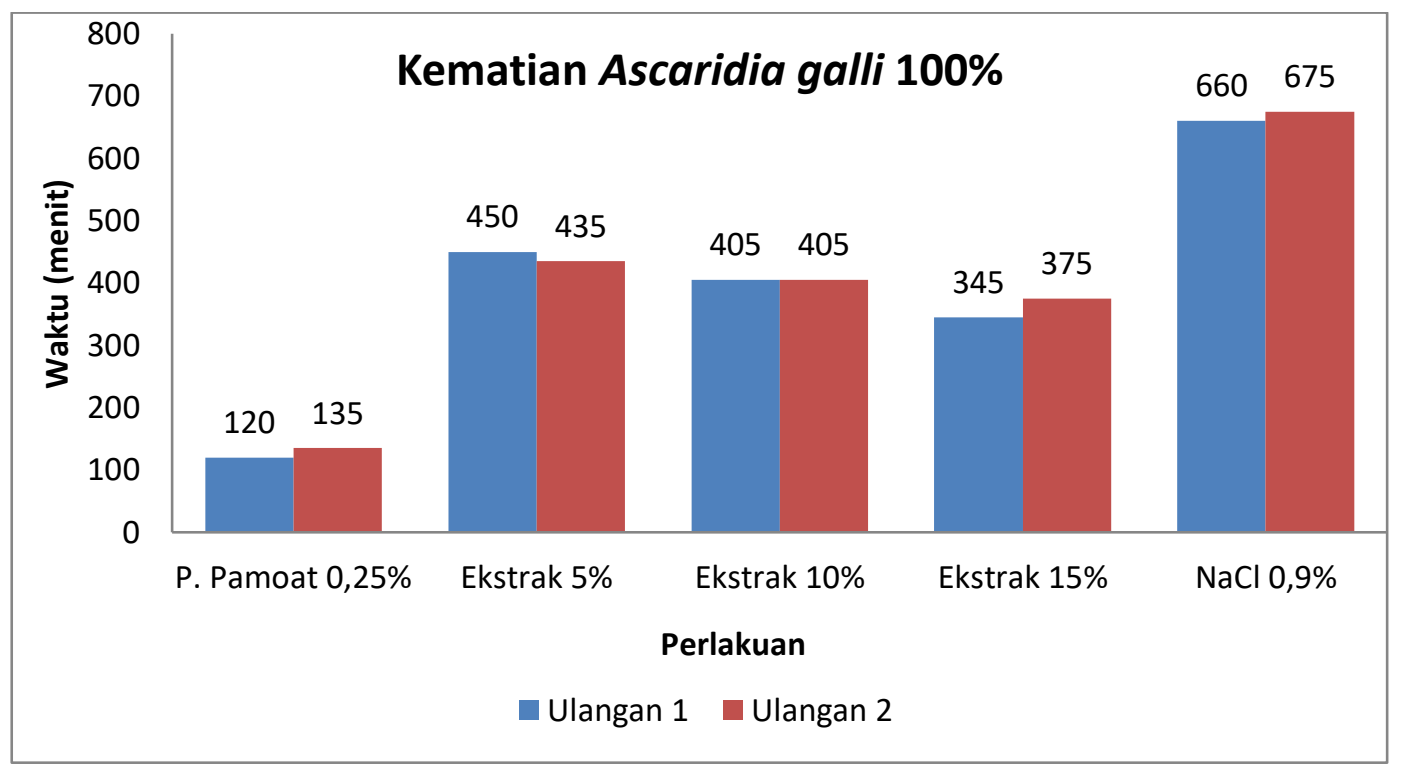

Gambar 2. Grafik Waktu Kematian Semua Cacing Ascaridia galli

Pada gambar 2 dapat dilihat adanya perbedaan aktivitas antelmintik dengan ditunjukkannya perbedaan waktu kematian konsentrasi, maka semakin cepat juga aktivitas antelmintik terhadap cacing Ascri dia galli.

Kematian cacing Ascaridia galliyang terjadi pada rendaman ekstrak etanol daun sukun, diduga karna adanya kandungan senyawa aktif yang bersifat toksik bagi cacing.Hasil uji fitokimia ekstrak etanol $96 \%$ daun sukun menunjukkan terdapatnya senyawa , flavonoid, alkaloid tanin, fenol dan saponin,diperkirakan memiliki peran yang dapat menyebabkan kematian pada cacing Ascaridia galli(Dara et al., 2017).

Tanin bekerja menginhibisi kerja asetilkolin yang mengkibatkan terganggunya proses absorbsi cacing sehingga cacing mati disebabkan terjadi kerusakan reproduksi dan nutrisi. Membran kutikula cacing dapat dirusak oleh tanin.Rusaknya membrane tubuh cacing akan mengakibatkan lebih permeabelnya tubuh cacing. terhadap senyawa-senyawa lain sehingga terjadi paralisis (Darmawi et al., 2016).

Kontak antara kulit cacing ekstrak dengan ekstrak akan menjadi lebih baik dengan menurunnya tegangan permukaan.. Turunnya tegangan permukaan ini disebabkan oleh senyawa saponin/ Saponin juga dapat menyebabkan iritasi pada membrane mukosa cacing. cacing Ascaridia galli pada masing-masing perlakuan.Dimana pada perlakuan ekstrak daun sukun ditunjukkan semakin tinggi.

Denaturasi protein di jaringan cacing akan menyebabkan cacing mengalami kematian. Senyawa tang berperan dalam proses ini adalaah flavonoid. Selain itu Flavonoid mendegenerasi neuron pada tubuh cacing sehingga dapat menimbulkan kematian (Supriati et al., 2012).

Fenol bekerja menginhibisi terbentuknya energi bagi cacing dan dapat mengikat glikoprotein di kutikula yang menyebabkan kematian cacing (Darmawi et al., 2016). Waktu kematian semua cacing Ascaridia galli pada perlakuan rendaman ekstrak etanol $96 \%$ daun sukun (Artocarpus altilis) terjadi selama 450 menit atau kurang dari waktu 9 jam.Ekstrak etanol daun sukun pada konsentrasi 5\% dan $10 \%$ memiliki aktivitas antelmintik lebih baik jika dibandingkan dengan aktivitas antelmintik yang dimiliki pada ekstrak biji pepaya (Marlin et al., 2009). Dimana ekstrak biji papaya pada konsentrasi 5\% dan 10\% memiliki aktivitas antelmintik sebesar 16,33 jam dan 9,33 jam, sedangkan ekstrak daun sukun pada konsentrasi $5 \%$ dan $10 \%$ memiliki aktivitas antelmintiksebesar 450 menit ( $\leq 9$ jam) dan 405 menit $(\leq 8$ jam). 
Pada penelitian ini dapat disimpulkan, rendaman ekstrak etanol $96 \%$ daun sukun konsentrasi 5\%, 10\% dan 15\% memipunyai aktivitas antelmintik terhadap cacing Ascaridia galli. Aktivitas antelmintik pirantel pamoat $0,25 \%$ lebih cepat dibandingkan dengan aktivitas antelmintik ekstrak etanol daun sukun konsentrasi 5\%, 10\% dan konsentrasi 15\%, karena pirantel pamoat bekerja menghambat enzim kolinesterase yang menyebabkan penumpukan asetikolin sehingga otot cacing mengalami hiperkontraksi (Sri dan Semmy, 2007). Hal ini memperlihatkan bahwa bahwa ekstrak etanol $96 \%$ daun sukun dengan konsentrasi 5\%, 10\% dan 15\% mempunyai aktivitas antelmintik lebih kecil jika dibandingkan dengan pirantel pamoat $0,25 \%$. (Artocarpus altilis), menjadi alasan untuk pene litian dan ini dapat dikembangkan lebih lanjut.

\section{KESIMPULAN}

Dari hasil penelitian dapat diambil simpulan sebagai berikut :

1-Hasil idenfitikasi fitokimia ekstrak etanol 96\% daun sukun (Artocarpus altilis) mengandung senyawa, flavonoid, saponin, alkaloid tanin dan fenol.

2-Aktivitas antelmintik ekstrak etanol 96\% daun sukun (Artocarpus altilis) memiliki

\section{DAFTAR PUSTAKA}

[1] [AOAC] Association of Official Analytical Chemist. 2000. Official Method 942.05 Ash of animal feed. AOAC Official Method.4: 6.

[2] Budhi, W., Tiwow, D., Kojong, N.S. 2013. Uji Efek Antelmntik Ekstrak Etanol Biji Pinang (Areca catechu) Terhadap Cacing Ascaris Lumbricoides Dan Ascaridia Galli Secara In Vitro. Jurnal Ilmiah Farmasi 2(2): 76-80.

[3] Darmawi., Maryam., Balqis, U., Hambal, M., Rusmaidar., Hamzah, A., et al. 2016. Aktivitas Antelmintik Biji Veitchia merrillii Terhadap Ascaridia galliSecaraIn Vitro. Trad Med J 21(2): 55-62.

[4] Dirjen POM. 2007. Farmakologi dan Terapi. Jakarta: FK UI.

[5] Harbone. 1987. Metode Fitokimia, Penuntun Cara Modern Menganalisa.
Walaupun ekstrak etanol $96 \%$ daun sukun (Artocarpus altilis) mempunyai aktivitas antelmintik lebih kecil dibandingkan dengan pirantel pamoat, bukan berarti ekstrak etanol daun sukun tidak efektif untuk digunakan sebagai obat cacing. Pada penelitian ini adanya aktivitas antelmintik pada ekstrak etanol daun sukun, memiliki peluang yang baik agar dapat dikembangkannya menjadi sediaan lain untuk penggunaan obat antelmintik khususnya pada penyakit ascariasis karenapada penggunaan pirantel pamoat, memiliki efek samping seperti sakit perut, diare, mual, kram perut, pusing dan sakit (Tjay, 2007). Beberapa kekurangan pirantel pamoat yang kemungkinan tidak terdapat pada ekstrak etanol $96 \%$ daun sukun

perbedaan yang signifikan dengan larutan kontrol positif yaitu pirantel pamoat $0,25 \%$. Pada penelitian ini menunjukkan kelompok perlakuan ekstrak etanol daun sukun dengan konsentrasi 5\%, 10\% dan 15\% memiliki aktifitas antelmintik lebih kecil dibandingkan dengan kontrol positif yaitu Pirantel pamoat $0,25 \%$.

Tumbuhan: K. Padmawinata, I. Sudiro. Bandung: Institut Teknologi Bandung. Hlm: 32-44.

[6] Joni, T., M. Rizky., R. Mariani., F. Alan. 2017. Uji Efek Ekstrak Etanol Daun Sukun (Artocarpus altilis (Parkinson Ex F.A.Zorn) Terhadap Penurunan Kadar Glukosa Darah, Kolesterol Total dan Gambaran Histopatologi Pankreas Tikus Putih Jantan (Rattus norvegicus) Hiperkolestrololemia Diabetes. Palu: Program Studi Sekolah Tinggi Ilmu Farmasi Pelita Mas. Hlm: 386-387.

[7] Kendyartanto, R. 2008. Uji Daya Antelmintik Infus Daun Dan Infus Biji Pare (Momordica charantia) Terhadap Cacing Gelang Ayam (Ascaridia galli) Secara In Vitro. Semarang: Universitas Diponegoro. Hlm: 6-8. 
7 | Herson Cahaya Himawan et, al.,( Aktivitas Antelmintik Ekstrak Etanol 96\% ...)

[8] Levine, N.D. 1990. Buku Pelajaran Parasitologi. Gatut, A., penerjemah. Yogyakarta: Gadja Mada University Press. Hlm: 178-180, 249.

[9] Marlin, R.K.Y., Devi, Y.J.A.M., Tri, A.Y.F. 2009.Daya Membunuh Cacing Ekstrak Biji Pepaya (Carica papaya) Pada Ayam Buras. Kupang: Program Studi Kesehatan Hewan Politeknik Pertanian Negeri Kupang. Hlm: 11-15.

[10] Rasmiliah, 2001. Ascariasis sebagai Penyalit Cacing yang Perlu Diingat Kembali.Info Kesehatan Masyarakat. $7(2): 88-105$.

[11] Rina, W., Ana, M., Yunisa, D.P. 2017. Uji Aktivitas Ekstrak Etanol Daun Pepaya (Carica papaya) Terhadap Waktu
Kematian Cacing Ascaridia galli Schrank Secara In Vitro. Yogyakarta: Poltekkes Bhakti Setya Indonesia. Hlm: 141-146.

[12] Sri, S., Semmy, D.R.2007. Efek Antelmintik Perasan Wortel (Daucus Carota) Terhadap Ascaridia Galli. Edisi VIII. Yokyakarta: Mutiara Medika. Hlm: 40-44.

[13] Supriati, H.S., Lasut, V.N., Yamlean, P.V.Y. 2012. Uji Efektivitas Antelmintik Infus Daun Ketepeng Cina (Casia alata L) terhadap cacing gelang Ascaris suum Secara In Vitro. Jurnal Ilmiah Kesehatan 2(2): 1-6.

[14] Tjay., Tan Hoan., Kirana, R. 2007. ObatObat Penting Khasiat, Penggunaan dan Efek-Efek Sampingnya. Edisi VI. Jakarta: PT. Elex Media Komputindo. Hlm 262. 